\title{
Studying hepcidin and related pathways in osteoblasts using a mouse model with insulin receptor substrate 1-loss of function
}

\author{
JIA LIU ${ }^{1,2}$, LING QIAN ${ }^{1}$, LINNA GUO $^{1}$ and YUNZHI FENG ${ }^{1}$ \\ ${ }^{1}$ Department of Stomatology, The Second Xiangya Hospital, Central South University, Changsha, Hunan 410011; \\ ${ }^{2}$ Department of Stomatology, Nanfang Hospital, Southern Medical University, Guangzhou, Guangdong 510515, P.R. China
}

Received October 29, 2016; Accepted July 11, 2017

DOI: $10.3892 / \mathrm{mmr} .2017 .7876$

\begin{abstract}
Hepcidin is one of the most important proteins in iron metabolism. In the present study, its role in iron metabolism and the associated signaling pathways involved was investigated in a mouse model with insulin receptor substrate 1-loss of function $\left(\mathrm{IRS}^{-/-}\right)$, and osteoblasts in the iron overload condition. Protein expression levels of hepcidin, interleukin 6 (IL-6), bone morphogenetic protein receptor $1 \alpha$ and ferritin demonstrated a significant increase in the liver of the $\mathrm{IRS}^{-/-}$mice compared with the $\mathrm{IRS}^{+/-}$and $\mathrm{IRS}^{+/+}$mice. Hepcidin levels in the jaw bone were also increased in the IRS $^{-/-}$mice (although not significantly). Furthermore, mRNA expression levels of bone morphogenetic protein 6 (BMP6) and ferroportin (FPN) were significantly increased in the liver of the IRS ${ }^{-/}$mice compared with the other two models, but no significant differences were observed in the transferrin receptor mRNA expression levels. Additionally, the mRNA expression of hepcidin, FPN and IL-6 was upregulated in osteoblasts after ferric ammonium citrate exposure, while the mRNA expression of BMP6 was inhibited. Collectively, the results of the present study indicated that hepcidin is involved in iron metabolism in IRS-1 $1^{-/}$mice via the signaling pathways involving BMP6 and IL-6. Furthermore, hepcidin is also involved in iron metabolism in osteoblasts under iron overload conditions. Therefore, hepcidin and its associated signaling pathway proteins may represent potential targets for the treatment of conditions associated with iron overload.
\end{abstract}

\section{Introduction}

Iron is an essential element for almost every organism, from animals to microorganisms (1). Iron-associated disorders occur in conditions of iron deficiency or iron overload $(2,3)$. Hepcidin

Correspondence to: Dr Yunzhi Feng, Department of Stomatology, The Second Xiangya Hospital, Central South University, 139 Renmin Middle Road, Changsha, Hunan 410011, P.R. China

E-mail: fyz660303@126.com

Key words: hepcidin, IRS1 ${ }^{-/}$mice, interleukin-6, bone morphogenetic protein-6, bone morphogenetic protein, receptor type $1 \mathrm{~A}$ is a micro-molecule polypeptide that is composed of 25 amino acids $(4,5)$ and is involved in the regulation of iron metabolism. It is mainly expressed in liver cells, but it is also expressed in fat cells (6), pancreatic $\beta$ cells (7) and bone marrow cells, including monocytes $(8,9)$, macrophages $(10)$ and neutrophils. Hepcidin regulates iron metabolism by binding to ferroportin (FPN), which is the only route for iron export, leading to its internalization and degradation (11). As a key element of iron metabolism, hepcidin is influenced by factors such as iron storage, inflammation, anoxia and erythropoiesis (12). The most two important signaling pathways for hepcidin expression are the bone morphogenetic protein 6 (BMP6) (13) and Janus kinase2/signal transducer and activator of transcription 3 (JAK2/STAT3) signal pathways (14). In the BMP6 signaling pathway, BMP6 binds to its receptor (BMPR) to activate the phosphorylation of mothers against decapentaplegic homolog (SMAD) 1, 5 and 8, which subsequently leads to the induction of hepcidin transcription. An integrated BMP signaling pathway is necessary for maintaining the expression of hepcidin; mutations or defects in any of the involved proteins lead to a reduction in hepcidin levels. For example, deletion of the genes encoding the BMP6 ligand (15), BMPR1 $\alpha$ (16), the BMP receptor hemojuvelin (13) and SMAD 4 (17), or addition of the BMP ligand inhibitor HJV.Fc (18), BMPR1 $\alpha-F c$, and the BMP1R $\alpha-L D N-193189$ inhibitor (16) can inhibit the expression of hepcidin. Furthermore, increase in the levels of interleukin (IL)-6 can also promote hepcidin expression via the JAK2/STAT3 signaling pathway $(19,20)$. Many studies have demonstrated that iron metabolism is associated with insulin resistance, diabetes, and obesity, and that hepcidin serves an important role in these conditions (21-24). For example, in some types of obesity (25) or in lean juveniles (26), abnormality in iron storage and certain metabolic risk markers are observed. Furthermore, the hepcidin level in the urine, serum and liver in patients with dysmetabolic iron overload syndrome was significantly higher than in patients with hereditary hemochromatosis or insulin resistance without iron overload $(27,28)$. It was also observed that hepcidin levels in obese children with nonalcoholic fatty liver disease was significantly higher than in obese children without the disease (29). In addition, hepcidin and ferritin are thought to be associated with the inflammatory status in obesity and type 2 diabetes $(22,23)$. One study has reported that iron overload can also induce insulin resistance in visceral adipose tissue as a result of hepcidin upregulation (24). 
The iron nutritional status is associated with bone metabolic abnormalities. For example, Weinberg $(30,31)$ indicated that iron overload was a risk factor for osteoporosis. Additionally, iron overload was recently reported to be associated with osteopenia, osteoporosis and osteomalacia (32-35). In addition, as an important iron regulatory factor, hepcidin is regarded as a therapeutic target for the treatment of osteoporosis in menopausal women (36). However, the molecular mechanism of iron metabolism under conditions of iron overload in patients with osteoporosis is unclear, especially regarding the role of hepcidin signaling pathways.

The insulin receptor substrate (IRS) family of proteins functions as a substrate for insulin receptors, and they comprise four members: IRS1, 2, 3 and 4. IRS1 is composed of 1231 amino acids and is mainly distributed in the muscle and liver. It serves a crucial role in the insulin signaling pathway. In the present study, a mouse strain carrying a spontaneous mutation that abolishes IRS-1 activity (IRS ${ }^{-/}$) was used. These mice were lean and the body development in embryonic phase was slow, and they had a lifespan of $<2$ weeks on average. These mice carried a nonsense mutation of the 57th serine (substitution of nucleotide $\mathrm{C}$ with $\mathrm{A}$ ) of insulin receptor substrate 1 (IRS1). A mutation of the 57 th amino acid of this protein led to the disappearance of its expression. In a previous preliminary study, it was demonstrated that these $\mathrm{IRS}^{-/-}$mice manifested osteogenesis imperfecta and adipogenesis imperfecta, and that the expression of BMPR1 $\alpha$, an important receptor in the hepcidin signaling pathway, was upregulated (37). Thus, this mouse model is suitable for investigation of iron metabolism in insulin metabolic abnormalities, where osteogenesis imperfecta is manifested as one of the main pathological changes.

Therefore, the present study hypothesized that iron metabolism is regulated via the insulin signaling pathway, which also can induce bone metabolism changes. In the present study, the role of hepcidin in iron metabolism and the signaling pathways involved in the IRS ${ }^{-/-}$mouse model were investigated. Additionally, an attempt was made to provide insight into the association between iron metabolism and the bone metabolic abnormalities by inducing an iron overload condition in osteoblasts, where hepcidin signaling pathway serves an important role.

\section{Materials and methods}

Animal model. The animals used were four 4-week-old wild-type C57BL/6J female mice ( $\mathrm{IRS}^{+/+}$mice) and four 4-week-old IRS ${ }^{+/-}$male mice heterozygous for IRS-1 provided by Prof. Zhou (Institute of Endocrinology and Metabolism, The Second Xiang-Ya Hospital of Central South University, Hunan, China). The present study was approved by the Ethical Committee of the Second Xiang-Ya Hospital of Central South University. The mice were bred in a sterile environment at a humidity of $50 \pm 10 \%$ that was temperature and light controlled (12-h night/12-h day cycle, $22 \pm 1^{\circ} \mathrm{C}$ ), and they were provided adequate food and water. Mice with different sex and genotypes were bred together due to the research design. Three weeks after birth, offspring were weaned off the mothers and their genotype was ascertained. Mice with different genotypes were used in this study, including wild-type mice $\mathrm{IRS}^{+/+}$, heterozygote mice IRS ${ }^{+/}$and homozygote mice IRS ${ }^{-/}$.
Mice were sacrificed 6 months following breeding, biochemical-associated analyses were then carried out.

Genotype identification. Tail DNA was extracted via the DNA extraction kit (Universal Genomic DNA Extraction kit, Takara Bio Inc., Otsu, Japan), after which polymerase chain reaction (PCR) amplification and enzyme cleavage were carried out. The enzyme-digested product was subsequently used for polyacrylamide gel electrophoresis. Firstly, $10 \mathrm{ml} 12 \%$ polyacrylamide gel were prepared using $4 \mathrm{ml}$ polyacrylamide, $3.39 \mathrm{ml}$ double distilled water, $2 \mathrm{ml} 5 \mathrm{x}$ tetrabromoethane, $70 \mu 1$ 10\% ammonium persulfate and $3.5 \mu \mathrm{l}$ tetramethylethylenediamine, all electrophoresis related reagents were purchased from Beyotime Institute of Biotechnology (Shanghai, China). Lastly, the genotype was determined using the gel imaging analysis system.

Western blot analysis. Mice were sacrificed by cervical dislocation after 6 months of breeding, livers were then extracted for analysis. Liver tissues were irrigated with sterile PBS to remove residual blood and cut into small pieces. Liver samples were ground post-fixation with liquid nitrogen; ultrasonic degradation was then used for tissue fluid extraction. The protein concentration was determined using the Bicinchronic Acid protein assay kit (Thermo Fisher Scientific Inc., Waltham, MA, USA). Proteins (10 $\mu \mathrm{g} /$ well) were separated by $10 \%$ SDS-PAGE and transferred to a nitrocellulose membrane. After blocking the membrane with 5\% bovine serum albumin in phosphate-buffered saline containing $0.1 \%$ Tween 20 at room temperature for $1 \mathrm{~h}$, the blotted membrane was probed with the relevant antibodies at $4{ }^{\circ} \mathrm{C}$ overnight, including IRS-1 (1:1,000; cat. no. ab40777, Abcam, Cambridge, MA, USA), IL-6 (1:1,000; cat. no. 12912, Cell Signaling Technologies, Inc., Danvers, MA, USA), hepcidin-25 (1:100; cat. no. ab30760, Abcam), $\beta$-actin (1:1,000; cat. no. 3700, CST Biological Reagents Co, Ltd, Shanghai, China), BMPR1 $\alpha$ (1:1,000; cat. no. ab38560, Abcam), GAPDH (1:1,000; cat. no. 5174, Cell Signaling Technologies, Inc.) and ferritin (1:2,000; cat. no. ab75973, Abcam) at specified dilutions. Following this, membranes were incubated with horseradish peroxidase-conjugated secondary antibodies at $37^{\circ} \mathrm{C}$ for 1 h (1:10,000; cat. no. ab97051/ab6789, Abcam). Blots were detected using enhanced chemiluminescent western blotting detection reagents (Amersham; GE Healthcare Life Sciences, Uppsala, Sweden). Membranes were probed with $\beta$-actin and GAPDH (as controls) to ensure equal loading of proteins.

Immunohistochemistry analysis. After mice sacrifice, liver and jaw bone tissue samples of the three mouse models were obtained and the jaw bone tissues were decalcified using $10 \%$ EDTA (38). These tissues were deposited in paraffin-recipient blocks. Subsequently, the paraffin tissue sections were dewaxed and rehydrated in a descending alcohol series (100, 95, 90, 80, 70 and 50\%). For antigen retrieval, the slides were heated in $0.01 \mathrm{M}$ sodium citrate buffer at $100^{\circ} \mathrm{C}$ for $3 \mathrm{~min}$. After blocking with 5\% bovine serum albumin (cat. no. ST023, Beyotime Institute of Biotechnology) for $1 \mathrm{~h}$ at $37^{\circ} \mathrm{C}$, the slides were incubated with anti-hepcidin antibody (1:200; cat. no. ab30760, Abcam) overnight at $4^{\circ} \mathrm{C}$. The slides were subsequently washed three times with phosphate-buffered saline and incubated with a horseradish peroxidase-conjugated 
secondary antibody (1:100; cat. no. ab97100; Abcam) for $1 \mathrm{~h}$ at room temperature. Each slide was treated with a diaminobenzidine solution (1:25; cat. no. P0203; Beyotime Institute of Biotechnology) at room temperature for $5 \mathrm{~min}$, and then prepared for microscope observation.

RNA extraction and reverse transcription-quantitative polymerase chain reaction $(R T-q P C R)$. RNA was extracted using TRIzol reagent (Invitrogen; Thermo Fisher Scientific, Inc.), and the total RNA concentration was determined using an ultraviolet spectrophotometer. Subsequently, the RNA was reverse transcribed to cDNA with an RT reagent kit (Takara Bio Inc.). RT-qPCR was carried out using SYBR green (Takara Bio Inc.) using the following primers: GAPDH: Forward, 5'-TGG CAAAGTGGAGATTGTT-3' and reverse, 5'-CTTCTGGGT GGCAGTGAT-3'; Hepcidin: Forward, 5'-CACCAA CTTCCC CATCTGCATCTT-3' and reverse, 5'-GAGGGGCTGCAG GGGTGTAGAG-3'; transferrin receptor (TfR)1: Forward, 5'-TGCTATAGGTCCTGAGGGCAT-3' and reverse, 5'-GGC ATACAGCTCAATGGAAGA-3'; TfR2: Forward, 5'-GAG TTGTCCAGGCTCACGTACA-3' and reverse: 5'-GCTGGG ACGGAGGTGACTT-3'; FPN; Forward, 5'-GTCATCCTC TGCGGAATCATCCTGA-3' and reverse, 5'-GAGACCCAT CCATCTCGGAAAGTGC-3'; BMP6: Forward, 5'-AGCACA GAGACTCTGACCTATTTTTG-3' and reverse, 5'-CCACAG ATTGCTAGTTGCTGTGA-3' and IL-6: Forward, 5'-GTA TGAACAACGATGATGCACTTG-3' and reverse, 5'-ATG GTACTCCAGAAGACCAGAGGA-3'. Thermocycling conditions constituted 40 cycles, including an initial denaturation at $95^{\circ} \mathrm{C}$ for $30 \mathrm{sec}$, then $95^{\circ} \mathrm{C}$ for $5 \mathrm{sec}, 60^{\circ} \mathrm{C}$ for $30 \mathrm{sec}$ and $95^{\circ} \mathrm{C}$ for $5 \mathrm{sec}$, and was terminated by a final extension at $60^{\circ} \mathrm{C}$ for $1 \mathrm{~min}$. The data were analyzed using the $2^{-\Delta \Delta \mathrm{Cq}}$ method (39).

Cell culture and treatment. The 3T3-E1 cells were obtained from the Cell Bank of the Shanghai Infrastructure for Public Research and Development of the Chinese Academy of Medical Sciences (Shanghai, China). 3T3-E1 cells were incubated in $\alpha$-minimum essential medium (cat. no. 12571048; Thermo Fisher Scientific, Inc.), containing 10\% fetal bovine serum (cat. no. 10099141; Thermo Fisher Scientific, Inc.), and the medium was changed every other day. When cells reached $70-80 \%$ confluence, they were digested using trypsin-EDTA (cat. no. 25300054; Thermo Fisher Scientific, Inc.). Following this, cells were harvested and seeded with the same number of cells in each well of six well plates (100,000 cells/well). Then, complete culture medium was added per well, and the cells were incubated for $24 \mathrm{~h}$ at $37^{\circ} \mathrm{C}$. Ferric ammonium citrate (FAC) (F5879, Sigma-Aldrich; Merck KGaA, Darmstadt, Germany) was added at concentrations of 50, 100 and $200 \mathrm{mM}$ to induce iron overload in these cells, and the plates were incubated for $72 \mathrm{~h}$ at $37^{\circ} \mathrm{C}$ in a $5 \% \mathrm{CO}_{2}$ atmosphere. The control group was left untreated.

Statistical analysis. Data are expressed as the mean \pm standard deviation and were analyzed by one-way analysis of variance followed by the Bonferroni's post hoc test when equal variance was assumed, or Dunnett's T3 test when equal variance was not assumed. Statistical analyses were performed in SPSS version 17.0 (SPSS, Inc., Chicago, IL, USA). P<0.05 was considered to indicate a statistically significant difference.

\section{Results}

Genotype identification. The $\mathrm{IRS}^{-/}$mice used in this study were lean, and their weight was $40-60 \%$ of the wild-type mice; this feature was useful for phenotype identification initially. Following this, DNA identification was performed using the tail tissue. The Taq1 enzyme was employed to cut off the DNA at the site of the C-A nucleotide mutation, and the resulting dissected DNA fragments were 192 and 143 bp. Gel electrophoresis was employed to separate the DNA fragments: Wild-type mice only exhibited the 143-bp fragment, the IRS ${ }^{-/}$ mice only exhibited the 190-bp fragment, and the IRS $^{+/-}$mice exhibited both the 143 and 190-bp fragments (Fig. 1A). The IRS1 protein levels were detected using western blotting and were significantly lower in the IRS ${ }^{-/}$mice compared with the IRS $^{+/+}$and IRS ${ }^{+/-}$mice (Fig. 1B).

Hepcidin levels in the liver and jaw bones in the different groups of mice. Hepcidin was widely expressed in the liver (as indicated by the black arrow in Fig. 2A). Hepcidin levels were significantly higher in the liver in the IRS ${ }^{-/}$mice compared with the $\mathrm{IRS}^{+/}$and $\mathrm{IRS}^{+/+}$mice. Furthermore, hepcidin levels in the IRS ${ }^{+/-}$mice were slightly higher compared with the IRS $\mathrm{I}^{+/+}$ mice (Fig. 2A). On the other hand, hepcidin levels in the jaw bone were low compared with in the in mice livers. However, it was observed that the hepcidin level in the jaw bone of $\mathrm{IRS}^{-/-}$mice was higher compared with in the other two mouse models (Fig. 2B).

Alterations at the protein and mRNA levels of hepcidin signaling pathway proteins in the liver of the different groups of mice. The protein expression levels of hepcidin, IL-6, and BMPR1 in the liver were higher in the $\mathrm{IRS}^{-/-}$mice compared with the IRS $^{+/-}$and IRS $^{+/+}$mice $(\mathrm{P}<0.05$, Fig. 3). Protein expression levels of BMPR $1 \alpha$ and ferritin in IRS $^{-/-}$mice were significantly higher compared with the IRS ${ }^{+/+}$mice $(\mathrm{P}<0.001$, Fig. 3). Additionally, protein levels of BMPR $1 \alpha$ in the IRS ${ }^{+/-}$ mice was significantly higher compared with the IRS ${ }^{+/+}$mice $(\mathrm{P}<0.05$, Fig. 3). No significant differences were observed in the protein expression levels of hepcidin and IL- 6 between IRS $^{+/-}$and IRS $^{+/+}$groups.

Regarding the mRNA expression levels, the BMP6 mRNA levels in $\mathrm{IRS}^{-/-}$mice were significantly increased compared with the other two groups ( $\mathrm{P}<0.001$, Fig. 4A). The FPN mRNA levels were significantly higher in the $\mathrm{IRS}^{-/-}$mice compared with the $\operatorname{IRS}^{+/-}\left(\mathrm{P}<0.001\right.$, Fig. 4B) and $\operatorname{IRS}^{+/+}(\mathrm{P}<0.01$, Fig. 4B), while there was no significant difference between the IRS ${ }^{+/}$ and IRS $^{+/+}$mice $(\mathrm{P}<0.05$, Fig. 4). There were no significant differences in the mRNA levels of TfR 1 and 2 among the three mouse models ( $\mathrm{P}<0.05$, Fig. $4 \mathrm{C}$ and $\mathrm{D})$.

Alterations in the mRNA expression levels of hepcidin signaling pathway proteins in osteoblasts after ferric ammonium citrate exposure. After treatment with FAC at various concentrations, the mRNA expression levels of hepcidin, FPN and IL-6 significantly increased compared with the control group $(\mathrm{P}<0.001$, Fig. 5), with the peak mRNA levels observed at the FAC concentration of $100 \mathrm{mM}$. However, the BMP6 mRNA level declined compared with the control group $(\mathrm{P}<0.001$, Fig. 5), with the minimum level observed at the concentration of $100 \mathrm{mM}$. 
A

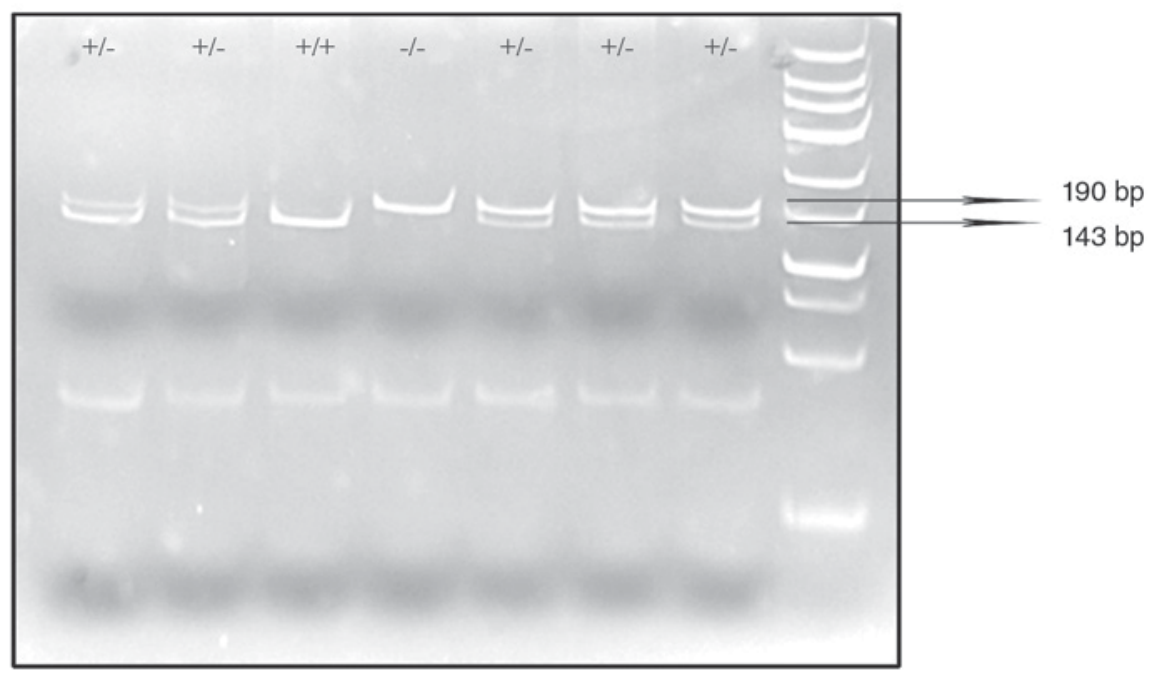

B
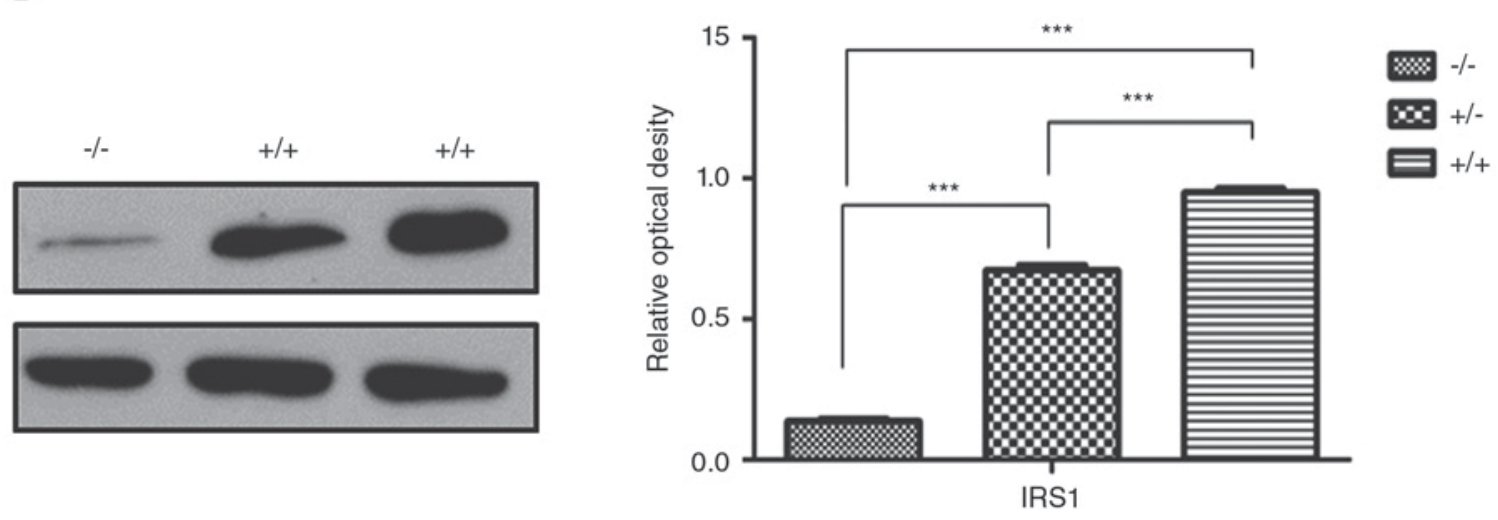

Figure 1. Identification of the IRS ${ }^{-/}$, IRS ${ }^{+/}$and IRS ${ }^{+/+}$mice by (A) DNA genotyping and by (B) western blotting for IRS1 protein expression levels. Data are presented as the mean \pm standard deviation. ${ }^{* * *} \mathrm{P}<0.001$. IRS, insulin receptor substrate. IRS, insulin receptor substrate $1 ;-/-$, loss of function; +/-, heterozygous; +/+, wild-type.
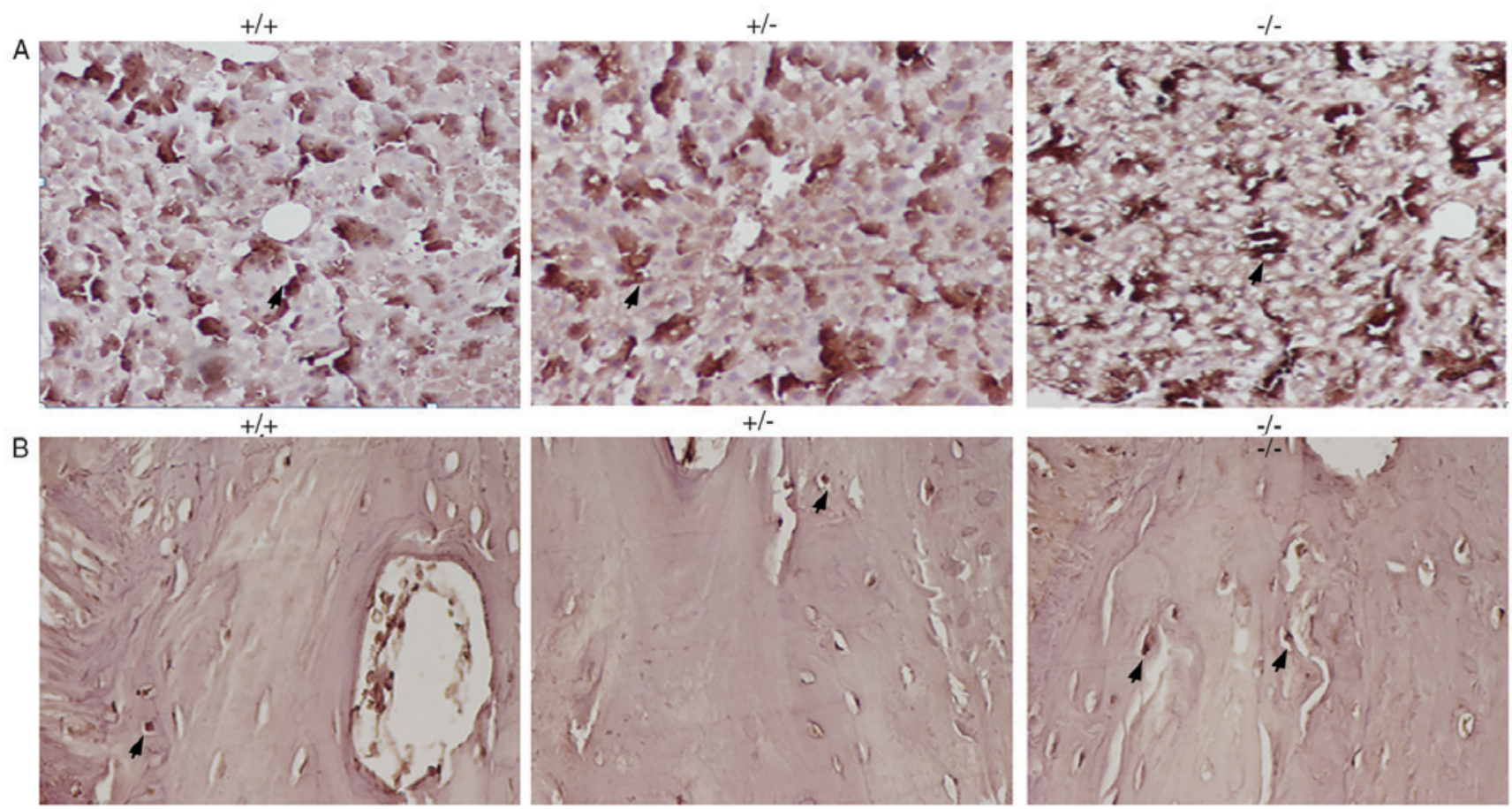

Figure 2. Representative immunohistochemistry images depicting hepcidin levels in the (A) liver and the (B) jaw bone of the IRS ${ }^{-/}$, IRS ${ }^{+/}$and IRS ${ }^{+/+}$mice, which were indicated by the black arrow. Magnification, x100. IRS, insulin receptor substrate. IRS, insulin receptor substrate 1; -/-, loss of function; +/-, heterozygous; +/+, wild-type. 

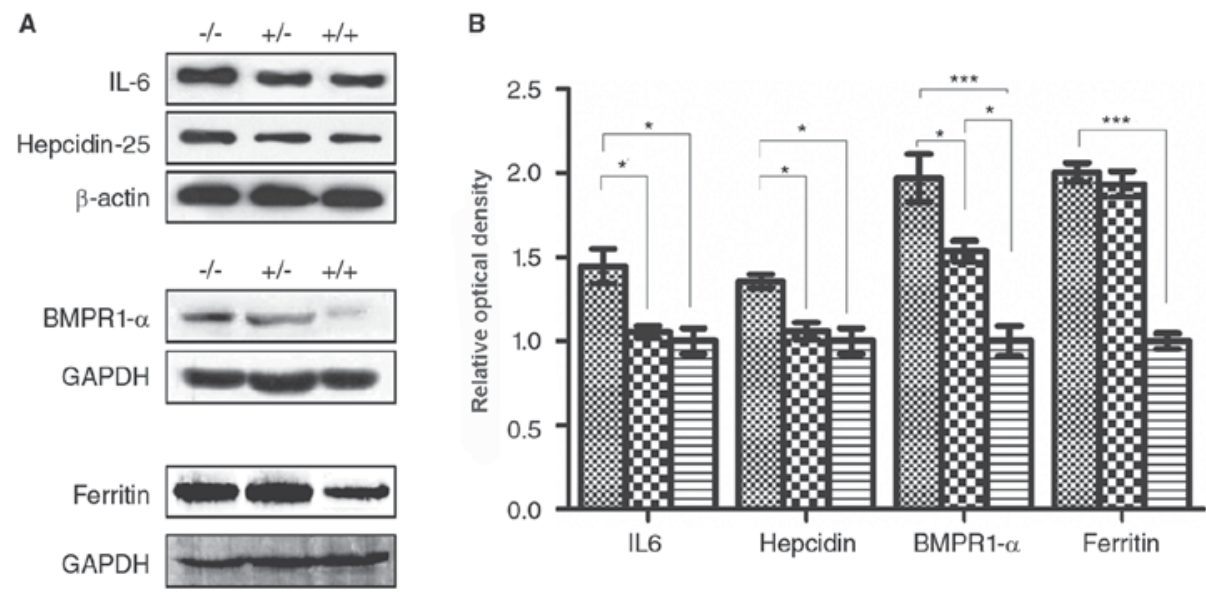

Figure 3. Protein expression analysis in the liver of $\mathrm{IRS}^{-/}$, IRS ${ }^{+/}$and IRS ${ }^{+/+}$mice. (A) Representative western blot images of IL-6, BMPR1 $\alpha$ and ferritin and (B) quantification. Data are presented as the mean \pm standard deviation. ${ }^{*} \mathrm{P}<0.05,{ }^{* * * *} \mathrm{P}<0.001$ vs. control (IRS ${ }^{-/}$) group. IL-6, interleukin 6 ; BMPR, bone morphogenetic protein receptor. IRS, insulin receptor substrate $1 ;-/-$, loss of function; +/-, heterozygous; +/+, wild-type.
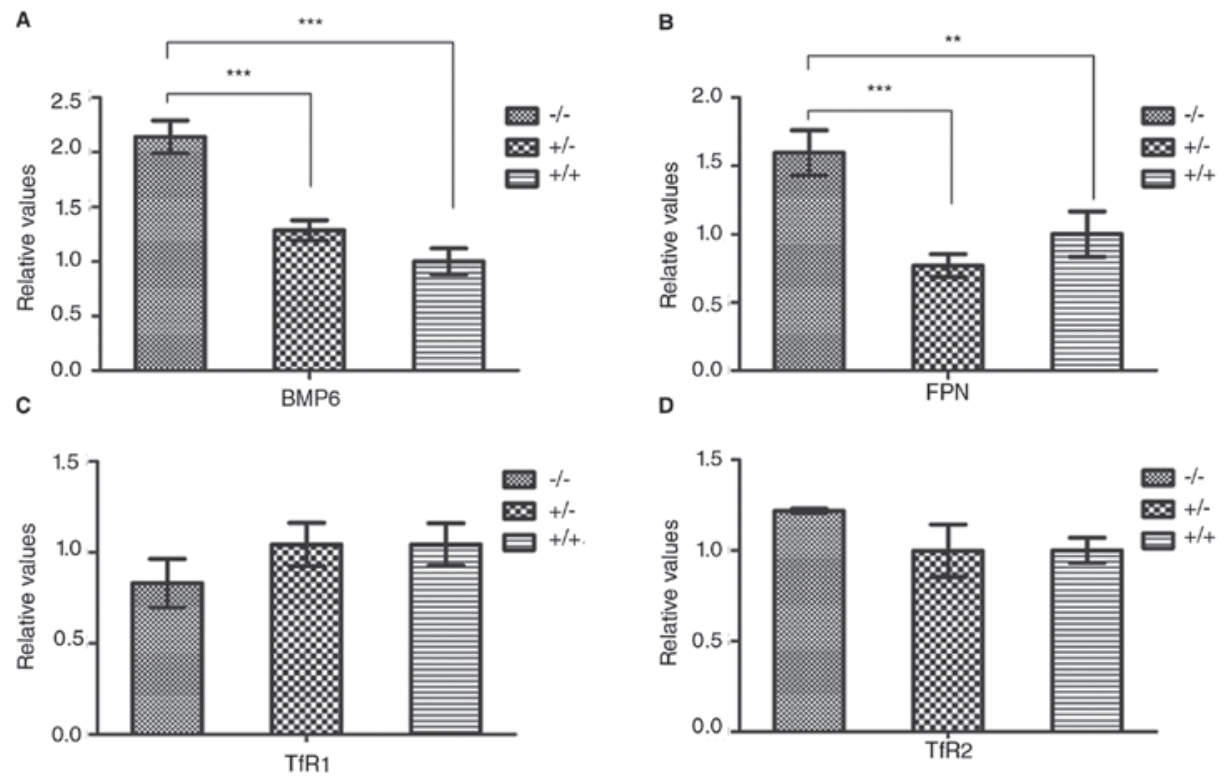

Figure 4. Relative mRNA expression levels of (A) BMP6, (B) FPN, (C) TfR1 and (D) TfR2 in the IRS ${ }^{-/}$, IRS ${ }^{+/}$and IRS ${ }^{+/+}$mice. Data are presented as the mean \pm standard deviation. ${ }^{* *} \mathrm{P}<0.01,{ }^{* * *} \mathrm{P}<0.001$ vs. control $\left(\mathrm{IRS}^{-/}\right.$) group. BMP6, bone morphogenetic protein 6; FPN, ferroportin; TfR, transferrin receptor.

\section{Discussion}

In the present study, the role of hepcidin in iron metabolism was examined in IRS-deficient mice and osteoblasts with iron overload induced via exposure to FAC. Furthermore, an attempt was made to elucidate the signaling pathways involved in the role of hepcidin in iron metabolism under the aforementioned conditions.

Hepcidin levels in the liver of IRS $^{-/}$mice was higher compared with in IRS ${ }^{+/}$and IRS ${ }^{+/+}$mice. Additionally, the hepatic protein expression levels of ferritin, which is considered as one of the main predictors of the iron level, were examined $(40,41)$. A significant increase in ferritin levels in the $\mathrm{IRS}^{-/}$and $\mathrm{IRS}^{+/}$ mice compared with in IRS ${ }^{+/+}$mice was identified. This finding implies that the iron storage levels in the IRS ${ }^{-/}$and IRS ${ }^{+/-}$mice models are high, and that iron overload is a possible condition within these two mouse models. Considering the significantly higher levels of hepcidin in the IRS ${ }^{-/}$mice, hepcidin may be involved with iron metabolism in this model.

In the present study, the protein expression levels of BMPR $1 \alpha$ were significantly elevated within IRS $^{-/}$mice, in accordance with the data obtained via microRNA and PCR arrays in a previous study (37). In order to further understand the role of the BMP signaling pathway in hepcidin expression within IRS ${ }^{--}$mice, the mRNA expression level of BMP6 was studied via RT-qPCR analyses. The BMP6 levels within IRS ${ }^{-1-}$ mice were higher compared with in the other two genotypes. Thus, upregulation of BMPR $1 \alpha$ and BMP6 expression may have induced hepcidin expression in the liver of this mouse model. 

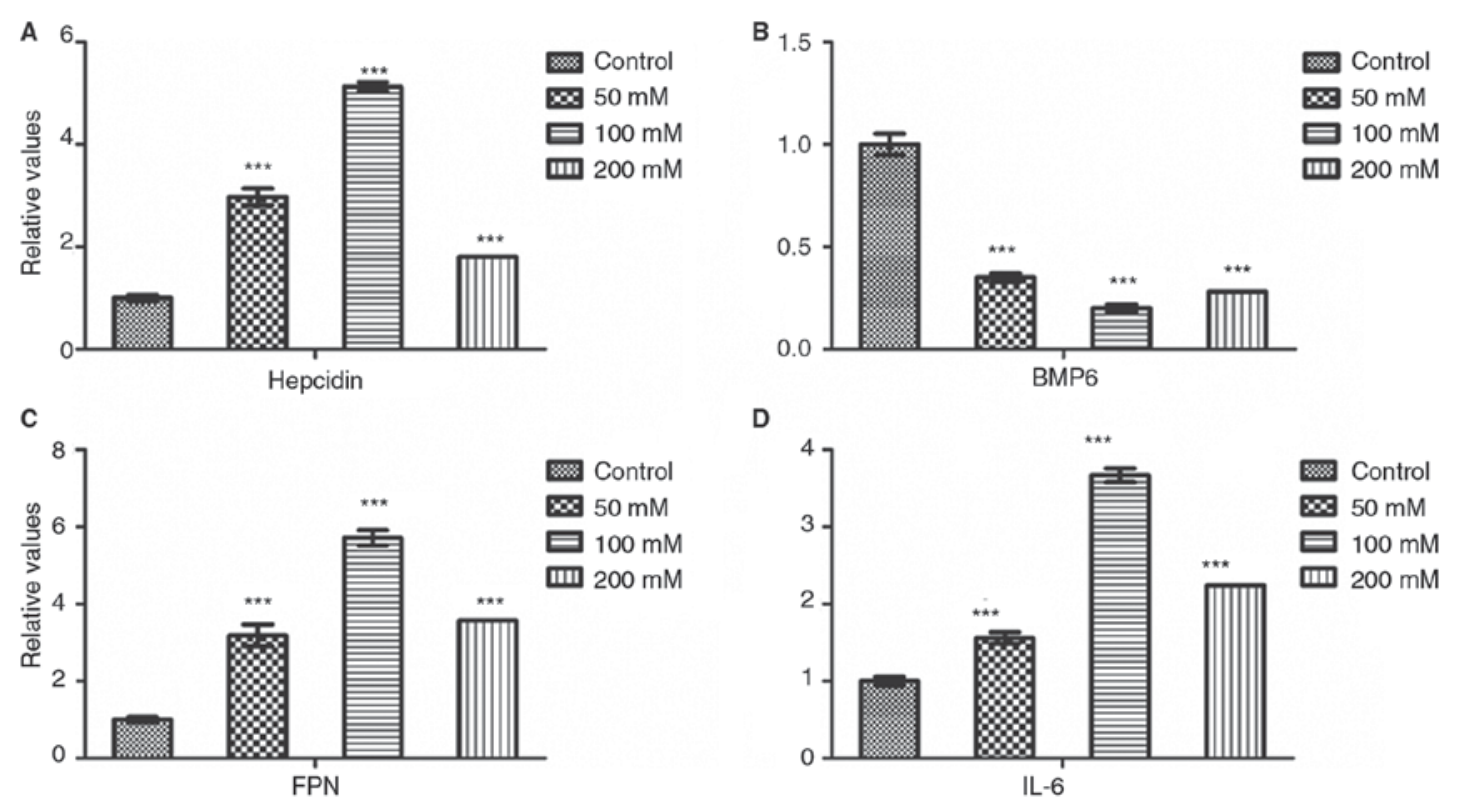

Figure 5. Relative mRNA expression levels of (A) hepcidin, (B) BMP6, (C) FPN and (D) IL-6 in osteoblasts after exposure with 10, 100, and $200 \mathrm{mM}$ ferric ammonium citrate. Data are presented as the mean \pm standard deviation. ${ }^{* * *} \mathrm{P}<0.001$ vs. control. BMP6, bone morphogenetic protein 6; FPN, ferroportin; IL-6, interleukin 6.

The JAK2/STAT3 signaling pathway is another important pathway for hepcidin expression, in which IL-6 serves a key role. A study has reported that the levels of hepcidin and proinflammatory factors were increased simultaneously in fat tissue and liver (42). Additionally, obesity is considered as a moderate inflammatory state characterized by high levels of hepcidin and TNF- $\alpha$ (28). Furthermore, some studies have reported that inflammatory factors, including liposaccharide, IL-6, IL-1- $\alpha$, and IL-1 $\beta$ can induce hepcidin expression in the liver $(19,43,44)$. In the present study, IL-6 expression was significantly increased in the IRS ${ }^{-/}$mice compared with in the other two models. IL-6 expression may be associated with the inflammatory status and the presence of adipogenesis imperfecta within $\mathrm{IRS}^{-/}$mice. Thus, upregulation of IL- 6 expression probably induced upregulation of hepcidin expression in this model.

TfR1 and TfR2 levels in the mouse liver were also examined, in order to understand the iron metabolism in the model mice. Tf is one of the most important carriers of iron, and many tissues obtain iron via TfRs. A study has reported that the TfR1 levels in hematochromatosis and non-alcoholic fatty liver disease (NAFLD) patients with iron overload were lower than those of NAFLD patients with iron deficiency (28). However, in the present study there were no significant differences in the TfR levels between the mice models. Therefore, TfR levels may not be affected within the liver of IRS ${ }^{-/}$mice. Notably, the mRNA expression levels of FPN, the only iron exportation protein (45), was higher in the IRS ${ }^{-/}$mice than in the $\mathrm{IRS}^{+/-}$and $\mathrm{IRS}^{+/+}$mice. A possible reason for this is that increased hepcidin expression in the IRS ${ }^{-/}$mice promoted intracellular iron overload, leading to higher FPN expression.

The findings of the present study indicated that the hepcidin and iron levels are increased in the liver of the $\mathrm{IRS}^{-/-}$mice, and that the BMP6 and IL-6 signaling pathways are the main factors involved in the alteration of hepcidin levels. However, alterations in iron status may induce systemic changes, such as osteoporosis. Previous data have indicated that iron overload can induce osteoporosis $(35,46)$. Furthermore, several studies have indicated the direct relationship between iron overload and osteoporosis, wherein hepcidin serves a crucial role (47-49). In the present study, osteogenesis imperfecta was a characteristic of the IRS ${ }^{-/}$mice. Additionally, an increase in the hepcidin levels in the jaw bone of IRS ${ }^{-1-}$ mice was detected, even though the levels were low in all animal models. Thus, hepcidin and iron status may be associated with bone metabolism since abnormal iron metabolism may induce bone metabolic abnormality, such as osteoporosis.

In order to improve understanding of the association between hepcidin and bone metabolism the hepcidin signaling pathways was further investigated in an osteoblast cell line with iron overload condition. Previous studies have indicated that iron overload induced biological activity changes to osteoblasts, including iron metabolism and the osteogenic effect (50-53). These data indicated that iron may serve an important role in osteogenesis and that iron deficiency and iron overload may inhibit osteoblast differentiation and development, respectively. Furthermore, hepcidin expression is associated with bone metabolism. Hepcidin promotes osteoblastic differentiation and mineralization by regulating the expression of alkaline phosphatase and osteogenic genes (54) or by increasing intracellular iron levels (48). Hepcidin knockout mice have been reported to have developed defects in bone microarchitecture and alterations in bone formation markers (55). In the present study, the mRNA expression levels of BMP6, an important bone morphogenetic protein for endochondral ossification, was reduced following FAC treatment which was not in accordance with the results in the IRS ${ }^{-/}$mice, and this effect was more evident at a concentration of $100 \mathrm{mM}$. This may due to the iron overload induced by FAC, which inhibited the expression of osteogenesis-associated proteins. Additionally, it has been reported that the expression level 
of BMP6 varied across different tissues under iron overload conditions (56). In the present study, the IL-6 mRNA expression levels were increased in osteoblasts after FAC exposure. Excess iron may induce oxidative stress leading to an inflammatory state, as evidenced by the increase in the expression of inflammatory factors $(57,58)$. Thus, IL-6 may be involved in hepcidin induction within osteoblasts via the JAK2/STAT3 signaling pathway following FAC treatment. Finally, the increased mRNA expression levels of FPN may due to the iron overload condition, as FPN promoted iron exportation to maintain the intracellular iron balance.

In conclusion, the present study indicated that IRS1 deficiency may result in a significant increase in hepcidin expression and alterations in the expression levels of associated signaling pathway proteins. The upregulation of hepcidin expression levels within the liver and jaw bone of IRS efficient mice may due to the increased expression of BMPR $1 \alpha$ and IL-6 via the BMP6 and JAK2/STAT3 signaling pathways. Therefore, hepcidin may be closely associated with iron metabolism via the BMP6 and JAK2/STAT3 signaling pathways in the IRS ${ }^{-/-}$mice model. Furthermore, IRS1 may serve a role in the hepcidin-associated signaling pathways; however, further investigation is required. Finally, iron overload was demonstrated to affect the mRNA expression levels of the hepcidin-associated genes within osteoblasts, but this also requires further investigation.

\section{References}

1. Arredondo M and Núñez MT: Iron and copper metabolism. Mol Aspects Med 26: 313-327, 2005.

2. Doom JR and Georgieff MK: Striking while the iron is hot: Understanding the biological and neurodevelopmental effects of iron deficiency to optimize intervention in early childhood. Curr Pediatr Rep 2: 291-298, 2014

3. Bardou-Jacquet E, de Tayrac M, Mosser J and Deugnier Y: GNPAT variant associated with severe iron overload in HFE hemochromatosis. Hepatology 62: 1917-1918, 2015.

4. Krause A, Neitz S, Mägert HJ, Schulz A, Forssmann WG, Schulz-Knappe P and Adermann K: LEAP-1, a novel highly disulfide-bonded human peptide, exhibits antimicrobial activity. FEBS Lett 480: 147-150, 2000.

5. Park CH, Valore EV, Waring AJ and Ganz T: Hepcidin, a urinary antimicrobial peptide synthesized in the liver. J Biol Chem 276 7806-7810, 2001.

6. Bekri S, Gual P, Anty R, Luciani N, Dahman M, Ramesh B, Iannelli A, Staccini-Myx A, Casanova D, Ben Amor I, et al: Increased adipose tissue expression of hepcidin in severe obesity is independent from diabetes and NASH. Gastroenterology 131 788-796, 2006.

7. Aigner E, Felder TK, Oberkofler H, Hahne P, Auer S, Soyal S, Stadlmayr A, Schwenoha K, Pirich C, Hengster P, et al: Glucose acts as a regulator of serum iron by increasing serum hepcidin concentrations. J Nutr Biochem 24: 112-117, 2013.

8. Theurl I, Theurl M, Seifert M, Mair S, Nairz M, Rumpold H, Zoller H, Bellmann-Weiler R, Niederegger H, Talasz $\mathrm{H}$ and Weiss G: Autocrine formation of hepcidin induces iron retention in human monocytes. Blood 111: 2392-2399, 2008.

9. Zhang $X$ and Rovin BH: Hepcidin expression by human monocytes in response to adhesion and pro-inflammatory cytokines. Biochim Biophys Acta 1800: 1262-1267, 2010.

10. Nguyen NB, Callaghan KD, Ghio AJ, Haile DJ and Yang F: Hepcidin expression and iron transport in alveolar macrophages. Am J Physiol Lung Cell Mol Physiol 291: L417-L425, 2006.

11. Nemeth E, Tuttle MS, Powelson J, Vaughn MB, Donovan A, Ward DM, Ganz T and Kaplan J: Hepcidin regulates cellular iron efflux by binding to ferroportin and inducing its internalization. Science 306: 2090-2093, 2004.

12. Jiang F, Sun ZZ, Tang YT, Xu C and Jiao XY: Hepcidin expression and iron parameters change in Type 2 diabetic patients. Diabetes Res Clin Pract 93: 43-48, 2011.
13. Babitt JL, Huang FW, Wrighting DM, Xia Y, Sidis Y, Samad TA, Campagna JA, Chung RT, Schneyer AL, Woolf CJ, et al: Bone morphogenetic protein signaling by hemojuvelin regulates hepcidin expression. Nat Genet 38: 531-539, 2006.

14. Wrighting DM and Andrews NC: Interleukin-6 induces hepcidin expression through STAT3. Blood 108: 3204-3209, 2006.

15. Meynard D, Kautz L, Darnaud V, Canonne-Hergaux F, Coppin H and Roth MP: Lack of the bone morphogenetic protein BMP6 induces massive iron overload. Nat Genet 41: 478-481, 2009.

16. Steinbicker AU, Bartnikas TB, Lohmeyer LK, Leyton P, Mayeur C, Kao SM, Pappas AE, Peterson RT, Bloch DB, Yu PB, et al: Perturbation of hepcidin expression by BMP type I receptor deletion induces iron overload in mice. Blood 118: 4224-4230, 2011

17. Wang RH, Li C, Xu X, Zheng Y, Xiao C, Zerfas P, Cooperman S, Eckhaus M, Rouault T, Mishra L and Deng CX: A role of SMAD4 in iron metabolism through the positive regulation of hepcidin expression. Cell Metab 2: 399-409, 2005.

18. Babitt JL, Huang FW, Xia Y, Sidis Y, Andrews NC and Lin HY: Modulation of bone morphogenetic protein signaling in vivo regulates systemic iron balance. J Clin Invest 117: 1933-1939, 2007.

19. Nemeth E, Rivera S, Gabayan V, Keller C, Taudorf S,Pedersen BK and Ganz T: IL- 6 mediates hypoferremia of inflammation by inducing the synthesis of the iron regulatory hormone hepcidin. J Clin Invest 113: 1271-1276, 2004.

20. Fleming RE: Iron and inflammation: Cross-talk between pathways regulating hepcidin. J Mol Med (Berl) 86: 491-494, 2008.

21. Al-Hakeim HK, Al-Khakani MM and Al-Kindi MA: Correlation of hepcidin level with insulin resistance and endocrine glands function in major thalassemia. Adv Clin Exp Med 24: 69-78, 2015.

22. Andrews M, Soto N and Arredondo-Olguin M: Association between ferritin and hepcidin levels and inflammatory status in patients with type 2 diabetes mellitus and obesity. Nutrition 31: 51-57, 2015.

23. Andrews Guzmán M and Arredondo Olguín M: Association between ferritin, high sensitivity C-reactive protein (hsCRP) and relative abundance of Hepcidin mRNA with the risk of type 2 diabetes in obese subjects. Nutr Hosp 30: 577-584, 2014.

24. Dongiovanni P, Ruscica M, Rametta R, Recalcati S, Steffani L, Gatti S, Girelli D, Cairo G, Magni P, Fargion S and Valenti L: Dietary iron overload induces visceral adipose tissue insulin resistance. Am J Pathol 182: 2254-2263, 2013.

25. Dubern B, Girardet JP and Tounian P: Insulin resistance and ferritin as major determinants of abnormal serum aminotransferase in severely obese children. Int J Pediatr Obes 1: 77-82, 2006.

26. Aigner E, Hinz C, Steiner K, Rossmann B, Pfleger J, Hohla F, Steger B, Stadlmayr A, Patsch W and Datz C: Iron stores, liver transaminase levels and metabolic risk in healthy teenagers. Eur J Clin Invest 40: 155-163, 2010.

27. Barisani D, Pelucchi S, Mariani R, Galimberti S, Trombini P, Fumagalli D, Meneveri R, Nemeth E, Ganz T and Piperno A: Hepcidin and iron-related gene expression in subjects with dysmetabolic hepatic iron overload. J Hepatol 49: 123-133, 2008.

28. Aigner E, Theurl I, Theurl M, Lederer D, Haufe H, Dietze O, Strasser M, Datz C and Weiss G: Pathways underlying iron accumulation in human nonalcoholic fatty liver disease. Am J Clin Nutr 87: 1374-1383, 2008.

29. Demircioğlu F, Görünmez G, Dağıstan E, Göksügür SB, Bekdaş M, Tosun M, Kızıldağ B and Kısmet E: Serum hepcidin levels and iron metabolism in obese children with and without fatty liver: Case-control study. Eur J Pediatr 173: 947-951, 2014.

30. Weinberg ED: Iron loading: A risk factor for osteoporosis. Biometals 19: 633-635, 2006.

31. Weinberg ED: Role of iron in osteoporosis. Pediatr Endocrinol Rev 6 (Suppl 1): S81-S85, 2008.

32. Matsushima S, Hoshimoto M, Torii M, Ozaki K and Narama I: Iron lactate-induced osteopenia in male Sprague-Dawley rats. Toxicol Pathol 29: 623-629, 2001.

33. Guggenbuhl P, Deugnier Y, Boisdet JF, Rolland Y, Perdriger A, Pawlotsky Y and Chalès G: Bone mineral density in men with genetic hemochromatosis and HFE gene mutation. Osteoporos Int 16: 1809-1814, 2005

34. Mahachoklertwattana P, Sirikulchayanonta V, Chuansumrit A, Karnsombat P, Choubtum L, Sriphrapradang A, Domrongkitchaiporn S, Sirisriro R and Rajatanavin R: Bone histomorphometry in children and adolescents with beta-thalassemia disease: Iron-associated focal osteomalacia. J Clin Endocrinol Metab 88: 3966-3972, 2003. 
35. Isomura H, Fujie K, Shibata K, Inoue N, Iizuka T, Takebe G, Takahashi K, Nishihira J, Izumi H and Sakamoto W: Bone metabolism and oxidative stress in postmenopausal rats with iron overload. Toxicology 197: 93-100, 2004.

36. Huang XI: Treatment of osteoporosis in peri- and post-menopausal women with hepcidin. US Patent 20100204122 A1. Filed Feb 11, 2010; issued April 7, 2015.

37. Guo Y, Tang CY, Man XF, Tang HN, Tang J, Wang F, Zhou CL, Tan SW, Feng YZ and Zhou HD: Insulin receptor substrate-1 time-dependently regulates bone formation by controlling collagen I $\alpha 2$ expression via miR-342. FASEB J 30: 4214-4226, 2016.

38. Park S, Kanayama K, Kaur K, Tseng HC, Banankhah S, Quje DT, Sayre JW, Jewett A and Nishimura I: Osteonecrosis of the jaw developed in mice: Disease variants regulated by $\gamma \delta \mathrm{T}$ cells in oral mucosal barrier immunity. J Biol Chem 290: 17349-17366, 2015.

39. Livak KJ and Schmittgen TD: Analysis of relative gene expression data using real-time quantitative PCR and the 2(-Delta Delta C(T)) method. Methods 25: 402-408, 2001

40. Ramanathan G, Olynyk JK and Ferrari P: Diagnosing and preventing iron overload. Hemodial Int 21 (Suppl 1): S58-S67, 2017.

41. Ratcliffe LE, Thomas W, Glen J, Padhi S, Pordes BA, Wonderling D, Connell R, Stephens S, Mikhail AI, Fogarty DG, et al: Diagnosis and management of iron deficiency in CKD: A summary of the NICE guideline recommendations and their rationale. Am J Kidney Dis 67: 548-558, 2016.

42. Dallalio G, Law E and Means RT Jr: Hepcidin inhibits in vitro erythroid colony formation at reduced erythropoietin concentrations. Blood 107: 2702-2704, 2006.

43. Nemeth E, Valore EV, Territo M, Schiller G, Lichtenstein A and Ganz T: Hepcidin, a putative mediator of anemia of inflammation, is a type II acute-phase protein. Blood 101: 2461-2463, 2003.

44. Lee P, Peng H, Gelbart T, Wang L and Beutler E: Regulation of hepcidin transcription by interleukin-1 and interleukin-6. Proc Natl Acad Sci USA 102: 1906-1910, 2005.

45. Bogdan AR, Miyazawa M, Hashimoto K and Tsuji Y: Regulators of iron homeostasis: New players in metabolism, cell death, and disease. Trends Biochem Sci 41: 274-286, 2016.

46. Tsay J, YangZ, Ross FP, Cunningham-Rundles S, Lin H, Coleman R, Mayer-Kuckuk P, Doty SB, Grady RW, Giardina PJ, et al: Bone loss caused by iron overload in a murine model: Importance of oxidative stress. Blood 116: 2582-2589, 2010.
47. Chen L, Zhu Z, Peng X, Wang Y, Wang Y, Chen M, Wang Q and Jin J: Hepatic magnetic resonance imaging with $\mathrm{T} 2 *$ mapping of ovariectomized rats: Correlation between iron overload and postmenopausal osteoporosis. Eur Radiol 24: 1715-1724, 2014.

48. Zhao GY, Di DH, Wang B, Huang X and Xu YJ: Effects of mouse hepcidin 1 treatment on osteoclast differentiation and intracellular iron concentration. Inflammation 38: 718-727, 2015.

49. Rossi F, Perrotta S, Bellini G, Luongo L, Tortora C, Siniscalco D, Francese M, Torella M, Nobili B, Di Marzo V and Maione S: Iron overload causes osteoporosis in thalassemia major patients through interaction with transient receptor potential vanilloid type 1 (TRPV1) channels. Haematologica 99: 1876-1884, 2014.

50. Yamasaki $\mathrm{K}$ and Hagiwara $\mathrm{H}$ : Excess iron inhibits osteoblast metabolism. Toxicol Lett 191: 211-215, 2009.

51. Messer JG, Kilbarger AK, Erikson KM and Kipp DE: Iron overload alters iron-regulatory genes and proteins, down-regulates osteoblastic phenotype, and is associated with apoptosis in fetal rat calvaria cultures. Bone 45: 972-979, 2009.

52. Messer JG, Cooney PT and Kipp DE: Iron chelator deferoxamine alters iron-regulatory genes and proteins and suppresses osteoblast phenotype in fetal rat calvaria cells. Bone 46: 1408-1415, 2010.

53. He YF, Ma Y, Gao C, Zhao GY, Zhang LL, Li GF, Pan YZ, Li K and $\mathrm{Xu}$ YJ: Iron overload inhibits osteoblast biological activity through oxidative stress. Biol Trace Elem Res 152: 292-296, 2013.

54. Li GF, Xu YJ, He YF, Du BC, Zhang P, Zhao DY, Yu C, Qin CH and Li K: Effect of hepcidin on intracellular calcium in human osteoblasts. Mol Cell Biochem 366: 169-174, 2012.

55. Shen GS, Yang Q, Jian JL, Zhao GY, Liu LL, Wang X, Zhang W, Huang X and Xu YJ: Hepcidin1 knockout mice display defects in bone microarchitecture and changes of bone formation markers. Calcif Tissue Int 94: 632-639, 2014.

56. Kautz L, Besson-Fournier C, Meynard D, Latour C, Roth MP and Coppin H: Iron overload induces BMP6 expression in the liver but not in the duodenum. Haematologica 96: 199-203, 2011

57. Chang JS, Li YL, Lu CH, Owaga E, Chen WY and Chiou HY: Interleukin-10 as a potential regulator of hepcidin homeostasis in overweight and obese children: A cross-sectional study in Taiwan. Nutrition 30: 1165-1170, 2014

58. Barbosa MC, Dos Santos TE, de Souza GF, de Assis LC, Freitas MV and Gonçalves RP: Impact of iron overload on interleukin-10 levels, biochemical parameters and oxidative stress in patients with sickle cell anemia. Rev Bras Hematol Hemoter 35: 29-34, 2013. 